\title{
REALITY AND VISION OF THE ARCHITECTURE FOR COGENERATION PLANTS FOR ENERGY RECOVERY
}

\author{
ILKOVIČ Ján ${ }^{1 *}$, MEZIANI Yakoub ${ }^{1}$ \\ ${ }^{1}$ Slovak University of Technology in Bratislava, Faculty of architecture and design, \\ Institute of Structure and Engineering Buildings, Námestie slobody 19, 81245 Bratislava 1, Slovakia, \\ e-mail: jan.ilkovic@stuba.sk
}

\begin{abstract}
Energetics is connected with industry development of the country and determines its geographic layout into certain extent. This fact defines an important and also priority position of energetics in a developed society. On the other side it evokes trying to reach sustainability of the environment and nowadays also trying to reach decreasing of the carbon footprint of human activities. The goal of the article is to present general criteria for localisation of energetic cogeneration plants on biogass base, factors presentation and confrontation of current examples and new trends in shaping architecture under the influence of the development of modern technique and technology. The article analyses mass-composition and architectonic aspects of energetic plants of the chosen performed examples and on the model studies it documents the vision of new solutions on the background of equal, non-invasive and eco-friendly architecture in the surroundings.
\end{abstract}

KEYWORDS: Energy, cogeneration, composition of architecture, sustainability, vision, eco-friendly solution

\section{Introduction}

Energy is in its transferred meaning life, it is a part of nature. It is everywhere around us and in different forms, whether it is free or chemically bound. Understanding of the time limit of the usage of fossil sources at the expense of next generations is the impulse for searching new solutions. The environmentalists today's energetic usage against nature call the global experiment with negative impact on the environment. The alternative sources will be effective when we accommodate their potential to their consumption. As a globally accepted alternative is considered the usage of biomass energy from agricultural and communal sphere. A human being perceives the energy mostly as a consumer, they have less information about its production, transition and of the context with the architectonic solutions of their power plants.

Cogeneration form of energy production is a term for a parallel production of more types of energy. The most common are examples for electric power and heat production and of three parallel energy media: electric power, heat and cool. Cogeneration - CHP is a widespread term for a combined production of electric power and heat. It is connected mainly with a combined production of power and heat while using the combustion engine.

Cogeneration is a modern technology of heat and electric energy production which requires a modern form of architecture. It has been successfully presented like this in advanced countries of the western Europe. It has got its share on keeping the sustainability, e.g. in Netherland, Germany and in Scandinavian countries not only in quality architecture but it also presents a decentralised form of production and localisation in cities.

The cogeneration plant with gas turbines is the optimal solution in general from the point of view of environmental impact, and thus the optimal solution for supplying with energy of an urban areas also [1]. 


\section{Material and Methods}

Cogeneration production of energy is relatively a new system in energetic industry and heating industries which is a result of efforts for sensible management with energies. It is a new part from a typological and architectonic view and it is necessary to be examined from the view of rules for design, localisation and interpretation of architecture.

The research of the issue was aimed for getting theoretical knowledge focused on:

- classification of cogeneration power plants,

- analysis of the chosen examples and categories of cogeneration plants (localization, form),

- defining of the factors of building and architecture regarding the most important production premises,

- characteristics of architecture of cogeneration production on the background of technology and architecture interaction (sustainability).

Opinions on solution of energetic situation are presented in conclusions which can be summed up in two levels: ecology (sustainability) and efficiency. The public must gradually start to respect energy as a social value similarily as historical sights or natural beauties [2]. Architecture is a part of such a challenge and it offers possibilities of a new relationship of technique and art.

Global development of the society in the future will depend to a great extent on situation in the energy area. This is the reason why building the electric power plants friendly to environment and using the sustainable energy sources will be a priority. Many authors have got the same opinion [3, 4]. Practical foreign experience are an architectonic impulse which can be generalised into the following points:

- Architecture of cogeneration plants in America uses the biggest technologies of cogeneration in its capacity which has got a relativelly negative impact on architecture. It has become to be only a kind of a shed for machines.

- Architecture of energetic facilities in the northern and western Europe (mainly Denmark, Netherlands, Spain) has got its longest tradition, it is the most numerous and this is also why it is on the highest level. Technological innovations are combined with modern, rational and inspirational architectonic expression of buildings and a construction detail.

As noted by slovak architect Martin Kusý (1976), important idea for the future are: Today it is evident that we have to consider the picture of our architecture in the overall picture of present worldwide architecture. This is the reason why architects will have to look more behind the borders of their countries.

\section{$3 \quad$ Results and Discussion}

Research works of many authors present a whole scale of issue from consumption effectivity to sources and analysis of new architectonic forms. Their basic motto is sustainability of environment. Lovins presented a concept of a so-called soft energy path in the context of life sustainability [5]. Kadrnožka established the sources classification, crucial characteristics and organisation of production premises of energetic file and he also focused on metodology of energy concept creation [6]. Hlaváček analysed development and theory of design of heating energetics buildings from the view of an architect [7]. Latest works are 
mainly those focused on usage of sustainable sources [8,9] and on architectonic forms of progressive evaluation of traditional and sustainable energy sources [10].

If we would like to evaluate architecture, at first we need to understand its function, size category, location and placement in an urban surroundings. These are the basic factors of architecture formation. According to the overall installed power the cogeneration plants are divided as follows:

1. category: micro-cogeneration with an installed power up to $50 \mathrm{~kW}$,

2. category: cogeneration of small power with an installed power up to $1 \mathrm{MW}$,

3. category: cogeneration of a middle power with an installed power between 1 to $10 \mathrm{MW}$,

4. category: cogeneration of a big power with an installed power bigger than 10 and up to $50 \mathrm{MW}$ (including the systems with a steam-gass cycle),

5. category: cogeneration of a big power with an installed power bigger than $50 \mathrm{MW}$

(including the systems with a steam-gass cycle).

The mission of an architect is to module a scheme determined by size categories together with a technologist. Technological processes must be continuously connected and they are the result of a well-considered object composition [7]. The functionalist motto form follows the function goes without saying at these constructions. This attitude is important mainly at creation of architecture which has got an attribute of being timeless, progressive and it uses modern technologies.

The research confirmed that nowadays technologically most modern equipment for energetics dispose of simple, clean and iconic architecture, is presented in Fig. 1, Fig. 2. They produce energy from waste and at the same time they provide education in situ for inhabitants - visitors about the whole technological cycle. It is documented by the example in Barcelona, Fig. 3, Fig. 4. Adding new eco-technologies on constructions (e.g. photovoltic pannels) contributes to enhancing the concept of sustainable architecture of the given facilities with sustainable technologies for production of safe energy in an effective way from re-newable resources [11].

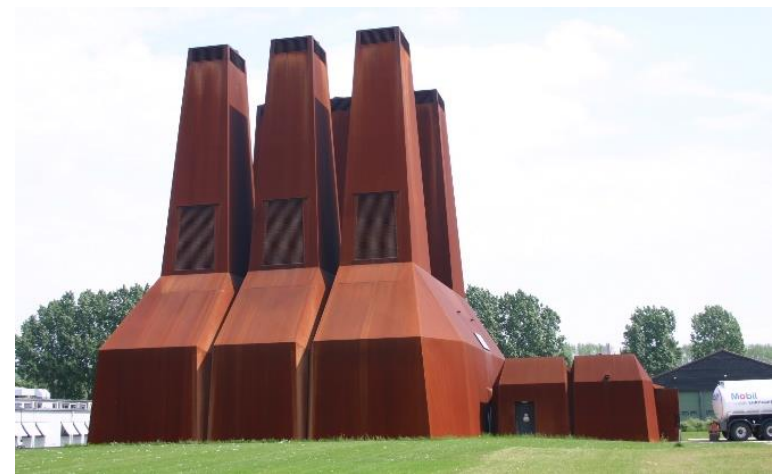

Fig. 1

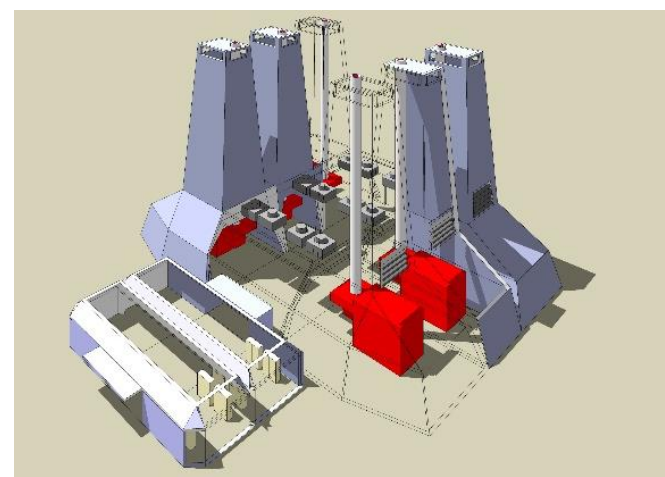

Fig. 2

Fig. 1 WKK Utrecht, Cogeneration facility, architect: Atelier Zeinstra van der Pol, photo authors. Fig. 2 Model of sculptural architecture and technology, study scheme, Y. Meziani

The most important form-creative unit is technology. Fuel accumulators (energetic silos), combustion aggregate (pots), technological units of cooling (cooling towers), waste (steal chimneys), parts of transformation and regulation are basic icons of energetic industry. It is not possible to characterize trends in architecture without frame knowledge of technological 


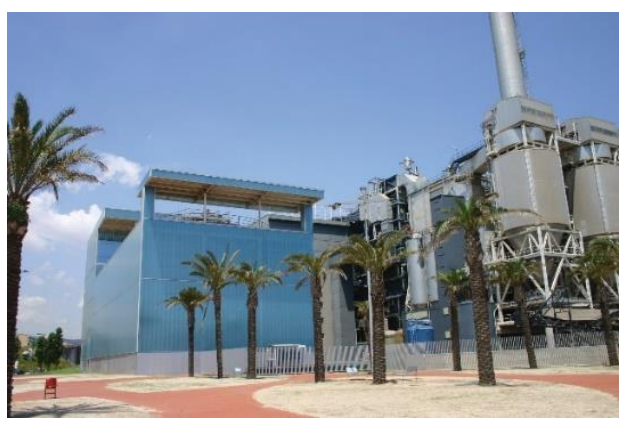

Fig. 3

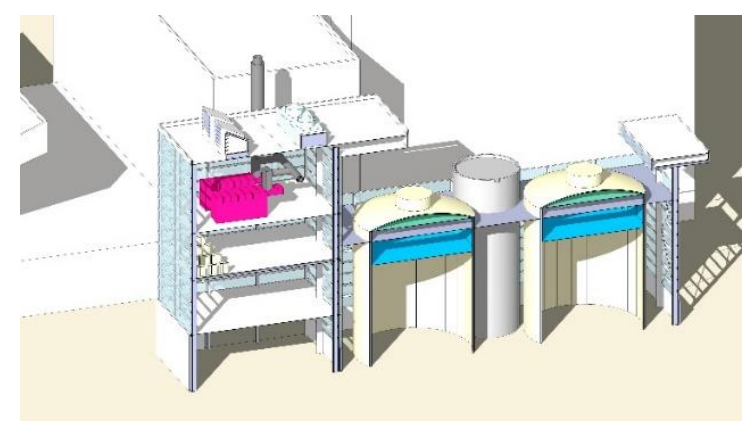

Fig. 4

Fig. 3 Ecopark 3 DEL Mediterrani, Barcelona, Architects Abalos \& Herreros Architecten, photo authors. Fig. 4 Section of technology part, study scheme, Y. Meziani.

innovations. Technologies are rationalised, their size lessens and at the same time they grow in power. This development trend is reflected in architecture in masses with small size with a packed or open technology. The first type shows technology and a function and the second one is presented by a technical design and legibility of a technological composition in the unit composition. Aesthetical dimension is moved into the level of technological units design and technological fragments carry an architectonic form. Based on analysis of architectonic forms (chosen particular solutions) architecture of productional energetic facilities can be divided into the following units:

1. a conventional form - it reflects traditional processes of the primary energy conversion with a dominant mass of an engine hall and a chimney while using the traditional expression tools, materials and an overall expression,

2. a sculptural form - meaningul modelling of mass for getting a monumental look at a minimal level of external technology demonstration,

3. high-tech form - mass modern (fashionable) formation with a purposeful exposure of technology fragments; architecture is dominated by expression items abstracting technique,

4. a combined form - it is a possible combination of units from previous forms.

Theoretical starting points were basis for choice of examples of cogeneration plants for analysis. One of the goal of the research was to perform a basic analysis of categories (1-5) and to find out characteristic qualities based on setting the indicators of area, space and technological setup. The chosen examples belong to quality architecture and they are mainly from northern states of Europe. Western and northern Europe has got a big advantage in construction of cogeneration heating plants, usage of biogass dominates here and also the combination of combustion of natural gass and biogass. The ambition of the research was to cover all the range of possibilities in area of productional categories and also in the area of relationship of architecture and technology. To compare relationships of architecture there were examples analysed on purpose from the following states: USA, Dominican republic, Denmark, Sweden, Netherland, Spain and Slovakia, Fig. 5.

The basic criteria for choice of examples were arranged as follows:

- the power of a heating plant (the crucial criteria),

- the basic source of energy,

- type of build-up area and technological setting,

- connection of architecture and technology,

- localisation and kind of a plant,

- quality of architecture and composition. 
A - category V

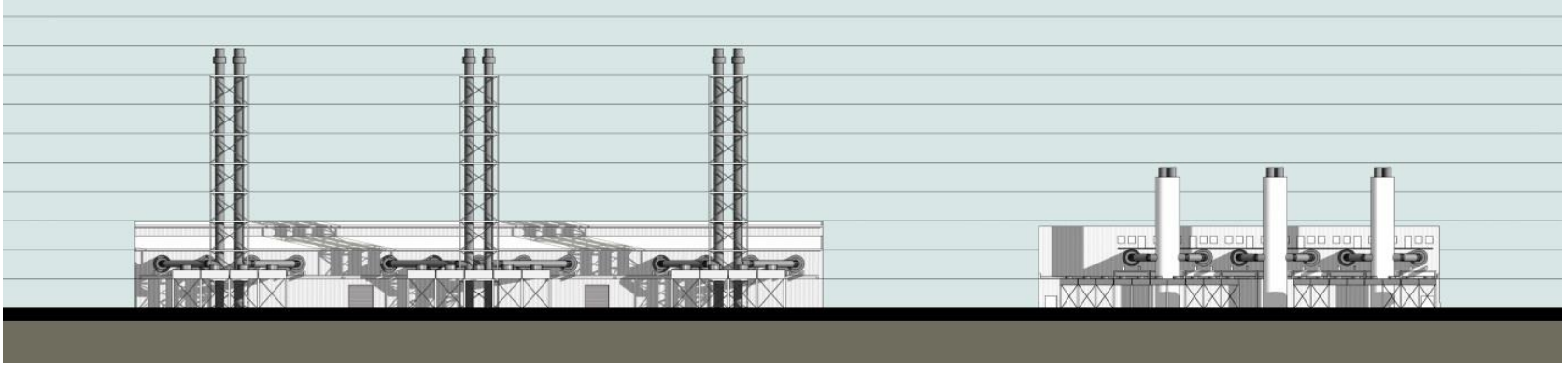

Monte Rio

Montana

B - category IV
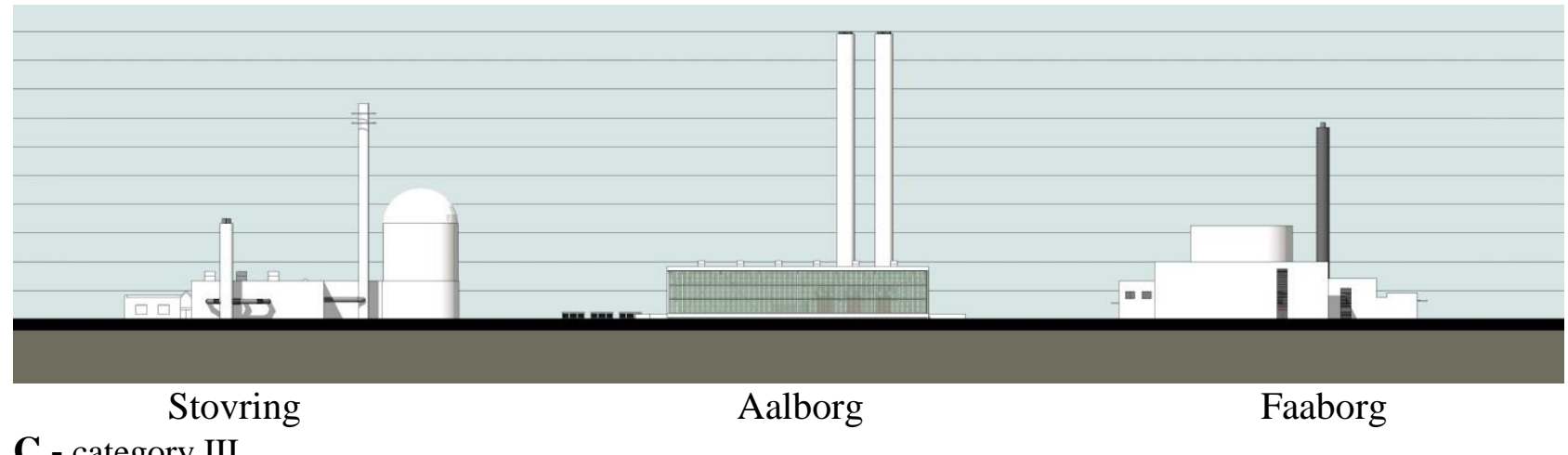

C - category III

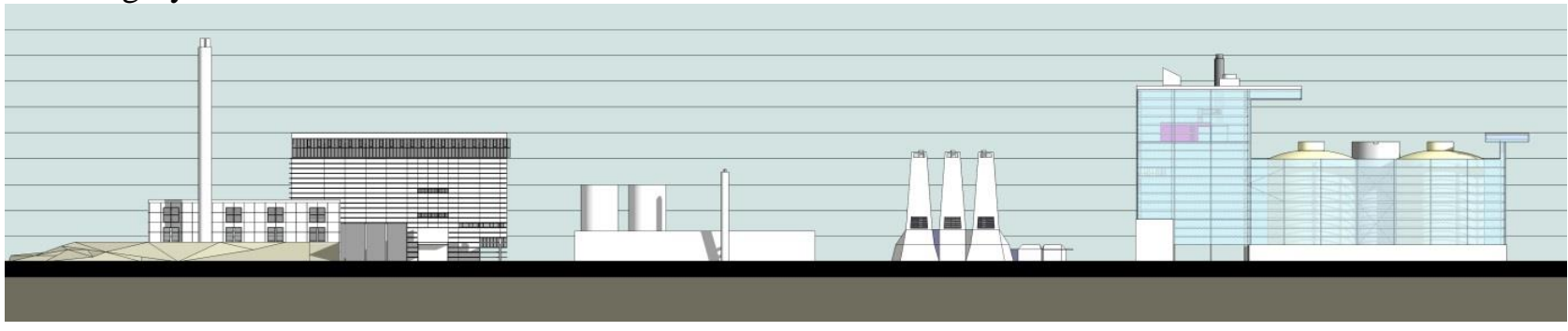

$\begin{array}{rrrr}\text { Svendborg } & \text { Soro } & \text { Utrecht } & \text { Barcelona } \\ \text { D - category II } & & & \end{array}$

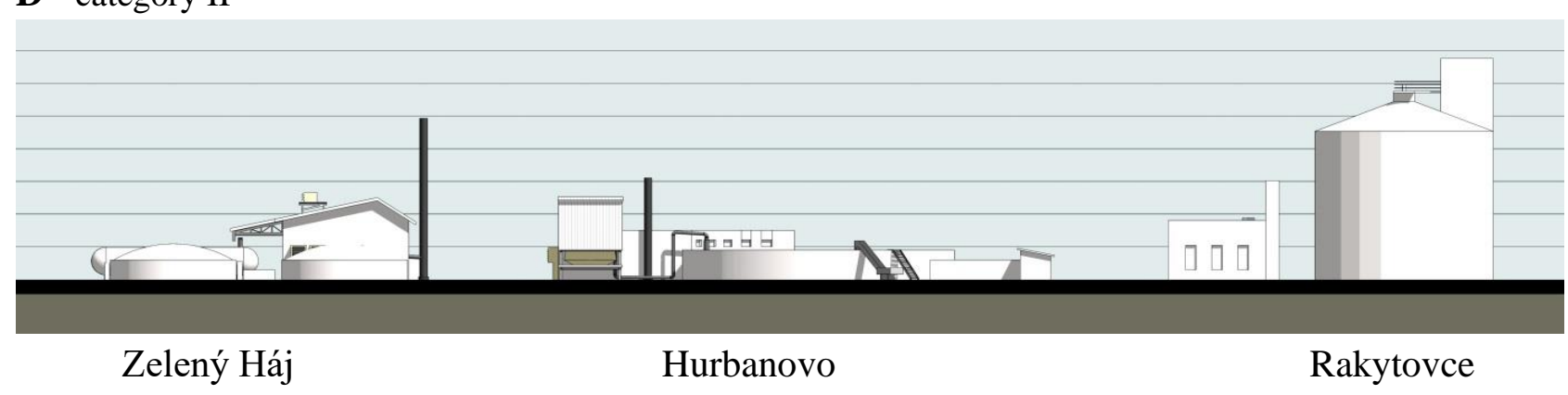

Fig. 5 Comparison of mass and proportional relations of analyzed cogeneration facilities in categories II - V, scheme: Y. Meziani.

Table 1 and graph in the Fig. 6 present monitored criteria and indicators. Indicators are in relative size dependent on production capacity only for Svenborg location and partially also Barcelona. Both locations are almost in all indicators not typical example, they show deviation from other examples.

Observation 1: There is a direct dependence of an overall power and followed indicators in the procedure line shown at a production facilities only with a function of cogeneration production. 
Table 1 Monitored criteria and indicators.

\begin{tabular}{|c|c|c|c|c|c|c|c|c|c|c|c|c|}
\hline \multicolumn{13}{|c|}{ Criteria and Indicators } \\
\hline 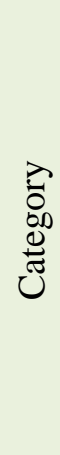 & \multicolumn{2}{|c|}{ 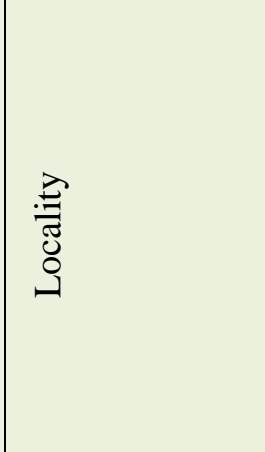 } & $\begin{array}{l}\sum_{\Xi}^{3} \\
\overline{0} \\
\vdots \\
0 \\
0\end{array}$ & 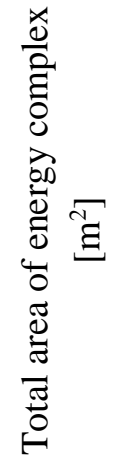 & 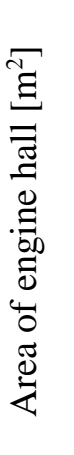 & 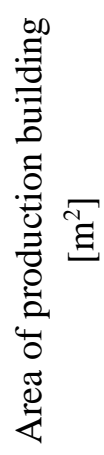 & 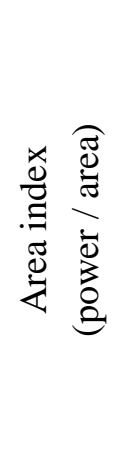 & 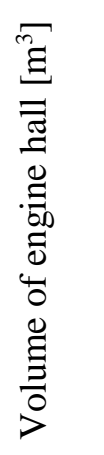 & 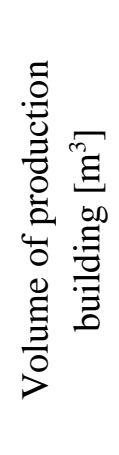 & 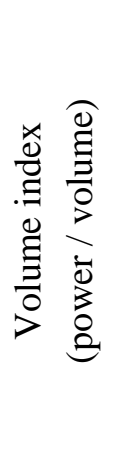 & 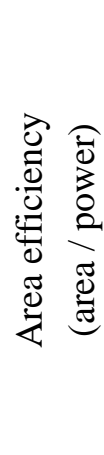 & 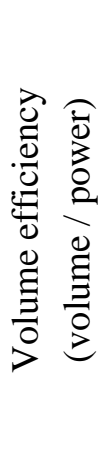 \\
\hline \multirow{2}{*}{ V } & 1 & Monte Rio & 74,1 & 45495 & 3991 & 5405 & 0,0186 & 39345 & 46245 & 0,0019 & 53,9 & 531 \\
\hline & 2 & Montana & 51,8 & 11815 & 2022 & 2490 & 0,0256 & 21500 & 26225 & 0,0024 & 39 & 415 \\
\hline \multirow{3}{*}{ IV } & 3 & Faborg & 16 & 15477 & 975 & 1820 & 0,0166 & $\overline{10786}$ & 19655 & 0,0015 & 60,2 & 665,8 \\
\hline & 4 & Aalborg & 15,6 & 6498 & 614 & 975 & 0,025 & 7368 & 11700 & 0,0021 & 39,4 & 472,3 \\
\hline & 5 & Stovring & 13,7 & 5430 & 910 & 1347 & 0,015 & 7280 & 12450 & 0,0019 & 66,4 & 531,4 \\
\hline \multirow{4}{*}{ III } & 6 & Svenborg & 9,3 & 22452 & 1232 & 4336 & 0,0076 & 18480 & 103080 & 0,0005 & 132,5 & 1987 \\
\hline & 7 & Soro & 7,0 & 1695 & 500 & 750 & 0,014 & 3307 & 8140 & 0,0021 & 71,43 & 472,4 \\
\hline & 8 & Utrecht & 6,4 & 6000 & 950 & 1100 & 0,0067 & 6000 & 9350 & 0,0010 & 148,4 & 937,5 \\
\hline & 9 & Barcelona & 2,2 & 1249 & 645 & 2100 & 0,0034 & 6133 & 61975 & 0,0004 & 293,2 & 2788 \\
\hline \multirow{3}{*}{ II } & 10 & Zelený Háj & 1,05 & 11125 & 204 & 579 & 0,0052 & 1428 & 4053 & 0,0007 & 194,3 & 1360 \\
\hline & 11 & Hurbanovo & 0,6 & 10644 & 128 & 174 & 0,0047 & 602 & 818 & 0,0010 & 213,3 & 1003 \\
\hline & 12 & Rakytovce & 0,5 & 4164 & 112 & 493 & 0,0044 & 784 & 3451 & 0,0006 & 224 & 1568 \\
\hline
\end{tabular}

Observation 2: The highest efficiency is shown in facilities with higher energetic power. At lower power the area of building increases including the area of engine hall which reflects technological connections. Facilities with a higher capacity are designed from a smaller number of cogeneration units with necessary unit power and necessary technological intervals. Demands on supplementory premises do not grow paralelly with power. The length of a machine grows most and also the demands on expansion of the hall space of engine hall. On the contrary, at smaller production capacities the area of unit grows and also the overall capacity.

Observation 3: Architecture of the mentioned cogeneration facilities can be put into three basic groups which in fact copy the size categories (categories II and III can be fused) with a possible localization also in regards of construction structure. Examples of V category are characterised as high-density which means at traditional technological sets the meaningfull solution, architectonically severe and simple in expression with using cheap surface materials. Their localisation is out of the city structure, in marginal and remote areas. They form independent production energetic areas.

Observation 4: Standard examples from Slovakia are not comparable from the view of quality of architecture. This fact shows that the issue of energetic constructions building is only at the start in Slovakia and this is the reason why research in this area is a highly topical and inspirative topic [12]. 


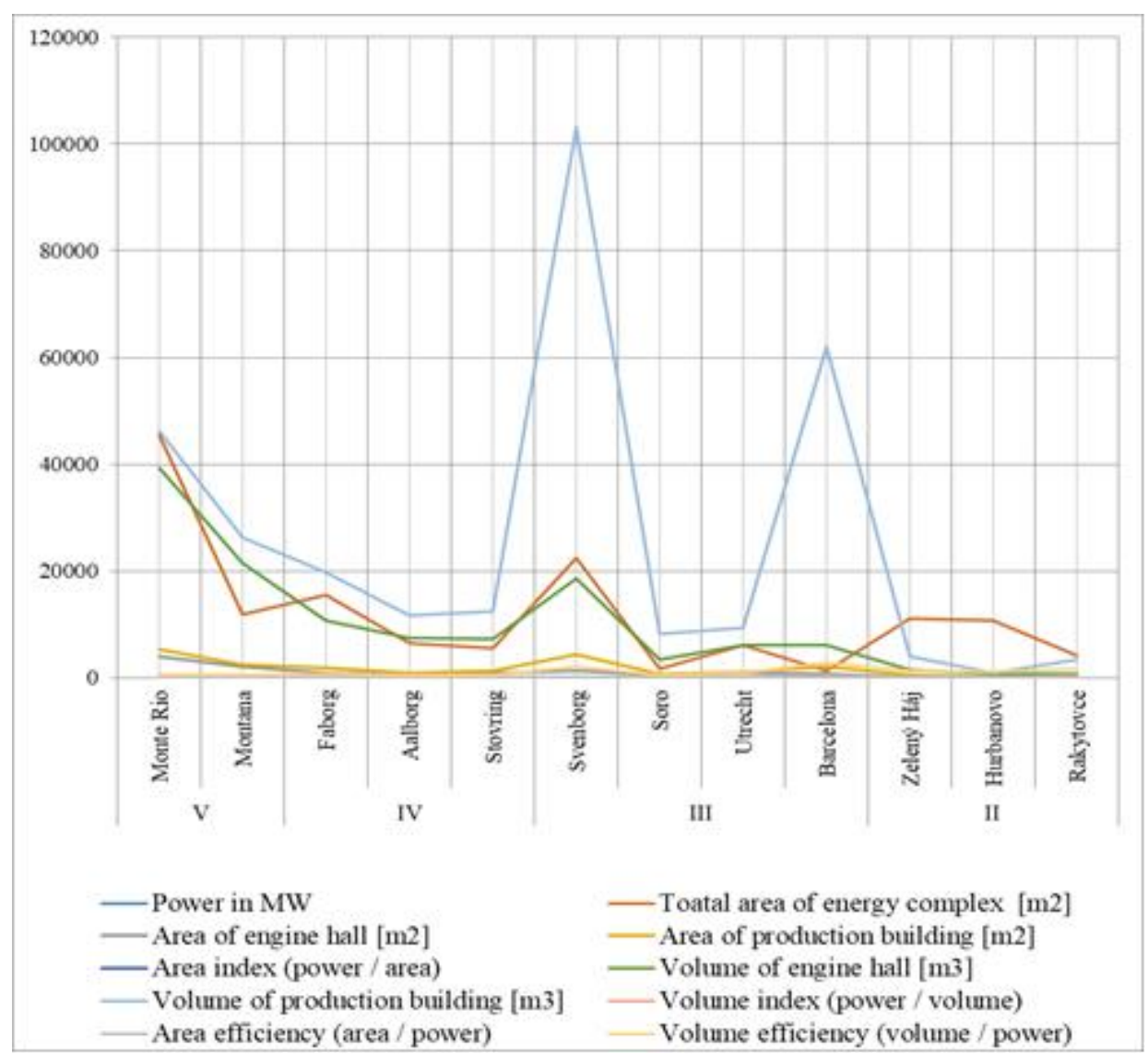

Fig. 6 Monitored criteria and indicators.

\section{CONCLUSION}

Visions of the next development of architecture will go parallely with development of cogeneration technologies and they depend on social interests in evaluation of biological waste. Biogass as a product of waste has not been appreciated up to now. From the point of function there will be intersection of purely productive energetic function with other activities. This is how the level of polyfunction and sustainability will be reached. The effort is to present mentioned plants as eco-friendly facilities. A person in this context has to understand the problem is not over by waste production and its disposal from the yard, it only starts there. An ideal situation is when everything bad (waste) changes in good (energy). Waste management is an important factor in environmental protection and an important source of efficient energy. $[13,14]$.

Numerous studies came to a conclusion that technologies of microcogeneration (micro $\mathrm{CHP}$ ) can contribute importantly to an instant economic and environmental advantages where the reduction of glasshouse emissions is shown, $[15,16]$.

Modern visual together with disposition and technological concepts of buildings present image buildings, educational multifunctional centres or on the contrary contextual architecture, [17], Fig. 6, Fig. 7. Thoughts which are essential at creation generally but important at architecture of energetic facilities where they navigate ideological flow, they form a concept, they are connected with sustainability and a certain form of visionary:

From the view of architecture the buildings for energy production should be transformed into a sign of the dawn of a climate-friendly future, [18]. 


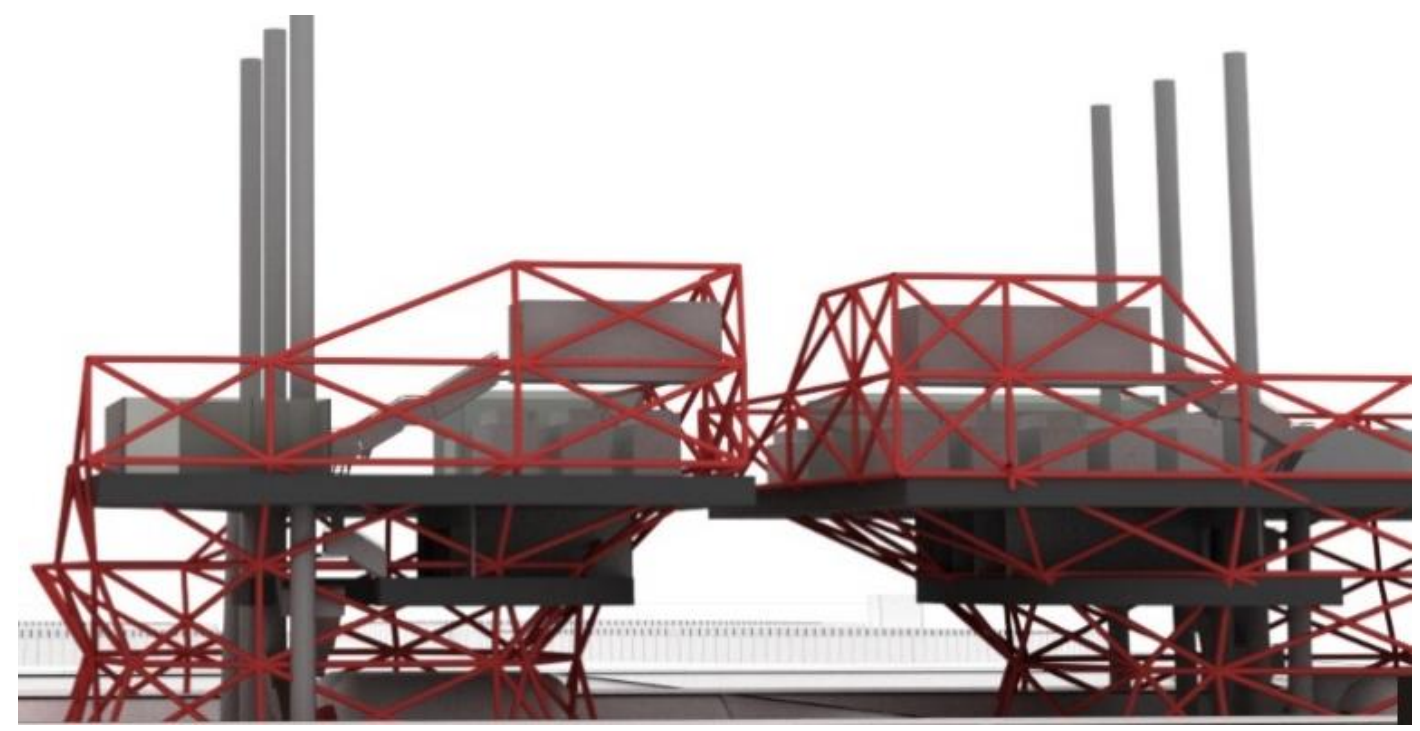

a)

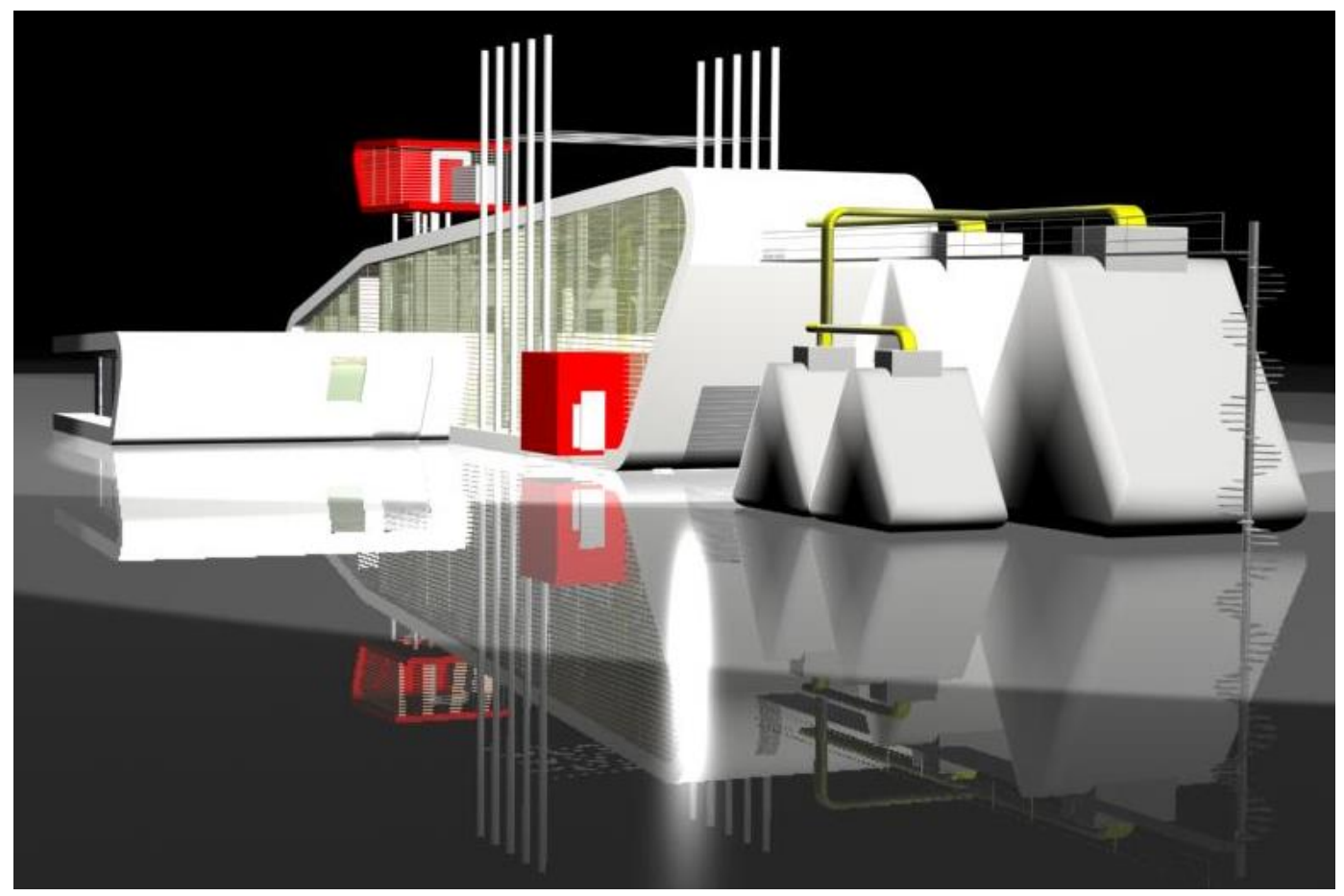

b)

Fig. 7Architectural visions of cogeneration facilities. Design studios - students: 7a) M. Lošonský 7b) P. Novotný, supervisor J. Ilkovič

\section{ACKNOWLEDGMETS}

This article was prepared under the grant project KEGA, Grant No. 037STU-4/2021.

\section{REFERENCES}

[1] Patrascu, R., Minciuc, E., Diaconescu, L. "Evaluation of the environmental impact of a cogeneration plant for an urban area", In: Thomas, G., Fleaurant, C., Panagopoulos, T., Chevassus-Lozza, T., Zaharim, A., Sopian, K. (eds.) Recent Researches in Energy, Environment and Landscape Architecture, WSEAS Press, Angers, France, pp. 118-121, 2011. 
[2] Špaček, R. "Energia je fyzika, biológia, ekonómia aj poézia", Eurostav, s.r.o., Bratislava, Slovakia, 12(1), pp. 22, 2006. ISSN 1335-1249. (in Slovak)

[3] Golušin, M., Dodić, S., Popov, S. "Strategic Priorities of Sustainable Energy Development", In: Golušin, M., Dodić, S., Popov, S. (eds.) Sustainable Energy Management, Academic Press, Elsevier, pp. 243 - 333, 2013. DOI: 10.1016/B978-0-12415978-5.00007-2

[4] David, A., Thangavel, Y. D., Sankriti, R. "Recover, Recycle And Reuse: An Efficient Way To Reduce The Waste", International Journal of Mechanical and Production Engineering Research and Development. 9(3), pp. 31 - 42, 2019. DOI: 10.24247/ijmperdjun20194.

[5] Lovins, A. B. "Soft energy paths: Towards a Durable Peace“, 1th ed., Friends of the Earth International, San Francisco, 1977, 231 p. ISBN 0-06-090653-7.

[6] Kadrnožka, J. “Tepelné elektrárny a teplárny“, 1th ed., SNTL, Praha, 1984, 607 p. (in Czech)

[7] Hlaváček, E. “Architektura pohybu a proměn“, 1th ed., Odeon, Praha, 1985, 167 p. (in Czech)

[8] Balák, R. "Nové zdroje energie“, 1th ed., SNTL, Praha, 1989, 208 p. ISBN 04-312-89. (in Czech)

[9] Šoch, J. "Výzkum a vývoj energetických zdrojů třetího tisíciletí", 1th ed., In: Obnovitelné zdroje energie, FCC PUBLIC, Praha, pp. 7-15, 1994. (in Czech)

[10] Ilkovič, J., Meziani, Y., Ilkovičová, L'. "Architektúra energetických výrobní na báze plynu“, 1th ed., Nakladatel'stvo STU, Bratislava, 2011, 168 p. ISBN 978- 80-227-36329. (in Slovak)

[11] Baldwin, E. "World's Largest Waste-to-Energy Plant Set to Open Next Year in Shenzhen", [online] Available at: https://www.archdaily.com/909843/worlds-largestwaste-to-energy-plant-set-to-open-next-year-in-shenzhen/ [Accessed: 18 November 2021].

[12] Ilkovič, J. "Nové trendy vo výstavbe energetických zariadení", Stavba, Bratislava, Slovakia, 5(2) pp. 17 - 21, 2002. ISSN 1335-5406. (in Slovak)

[13] Chríbik A., Polóni, M., Minárik, M. "Use of Methane-Free Synthesis Gases as Fuel in an Spark Ignition Combustion Engine“, Strojnícky časopis - Journal of Mechanical Engineering 70 (2), pp. 37 - 48, 2020. DOI: 10.2478/scjme-2020-0018

[14] Chríbik A., Polóni, M., Minárik, M. "Influence of Selected Synthesis Gas Component on Internal Parameters of Combustion Engine“, Strojnícky časopis - Journal of Mechanical Engineering, 69 (4), pp. 25 - 32, 2019. DOI: 10.2478/scjme-2019-0040

[15] Harrison, J. "What is Microgeneration? And what is the most cost effective in terms of $\mathrm{CO} 2$ reduction", [online] Available at: https://claverton-energy.com/what-ismicrogeneration.html [Accessed: 6 November 2008].

[16] Pehnt, M. "Environmental impacts of distributed energy systems - The case of micro cogeneration“, Environmental Science \& Policy, 11(1), pp. 25 - 37, 2008. DOI: $10.1016 /$ j.envsci.2007.07.001

[17] Gottlieb Paludan Architects, "Amager Power Station, BIO4", [online] Available at: https://www.gottliebpaludan.com/en/news/architecture [Accessed: 5 October 2020]. 
[18] Howarth, D. "Abandoned concrete bunker converted into a green power plant by IBA Hamburg“, [online] Available at: https://www.dezeen.com/2014/02/14/abandonedconcrete-bunker-converted-into-a-green-power-plant-by-iba-hamburg/

[Accessed: 14 February 2014]. 